\title{
DISTRIBUTION AND CONSERVATION STATUS OF NEOFELIS NEBULOSA (FELIDAE) IN ROYAL MANAS NATIONAL PARK, BHUTAN
}

\author{
Tashi Dhendup ${ }^{1,2}$ \\ ${ }^{1}$ Ugyen Wangchuck Institute for Conservation and Environmental Research, Bhutan \\ ${ }^{2}$ Wildlife Biology Program, University of Montana, USA \\ e-mail:tashid@uwice.gov.bt
}

Received: 09.05.2018

\begin{abstract}
The Clouded leopard Neofelis nebulosa is a globally threatened species, and very little is known about its ecology, distribution, population trends and threats. We used camera trap data from the 2013-2014 season of long-term monitoring of tigers in Royal Manas National Park in southern Bhutan to study the Clouded leopard distribution and to identify threats to the species and their habitat. Clouded leopards were recorded at 17 camera trap stations ( $25 \%$ of the total) within the park's jurisdiction of which ten stations were located inside the multiple use park management zone and seven in the core zone. The altitude of occurrence ranged from $243 \mathrm{~m}$ a.s.l. to $2323 \mathrm{~m}$ a.s.l. The species is facing ongoing threats from habitat degradation and loss, poaching, and climate change. Extraction of resources and developmental activities in Clouded leopard habitats inside the multiple use zone should be strictly supervised and studied. Continued effort is encouraged towards active monitoring particularly along the Indo-Bhutan border. There is also a strong need for dedicated ecological studies and a detailed assessment of threats to the species.
\end{abstract}

Key words: Bhutan, biodiversity, camera trap, Clouded leopard, conservation, habitat loss, poaching

\section{Introduction}

Threats to wildlife and its habitat should be identified well in advance, prioritised and actions should be taken to ensure that biodiversity persists into the future. Unsustainable management of resources from the natural ecosystem leads to widespread loss of pristine habitat and exploitation of species, driving them towards extinction (Wilting et al., 2006). One such a species affected by the loss of habitat and persecution is the Clouded leopard (Neofelis nebulosa (Griffith, 1821)).

The Clouded leopard (Fig. 1) is a mediumsized felid and is the least studied of the larger sized wildcats due to its secretive nature, nocturnal behaviour and low density (Gordon \& Stewart, 2007). The Clouded leopard is an umbrella species for the Asian forest ecosystem and can be found along the foothills of the Himalayas through Nepal, Bhutan, and India to South China, all the way down to Peninsular Malaysia, and on the islands of Sumatra and Borneo (Austin et al., 2007; Wilting et al., 2007). The species is listed as vulnerable on the IUCN Red List of Threatened Species and is facing a global decline in population and contraction in its geographic range. Their currently known habitats are undergoing the world's fastest regional deforestation rates (Grassman et al., 2016). Pelt and parts are also traded in the international illegal wildlife market.
The Clouded leopard (Neofelis nebulosa) is a protected species under the Forest and Nature Conservation Act of Bhutan (DoFPS, 1995), and therefore, hunting is strictly prohibited. Although Bhutan has pristine wildlife habitat in a contiguously protected area landscape, habitat fragmentation through infrastructure development in and around the protected areas pose a potential threat to many species including the Clouded leopard (Penjor, 2015). The Royal Manas National Park is a hotspot of felid diversity (Tempa et al., 2013) and harbours Clouded leopards co-existing with six other felid species (Dhendup et al., 2016). Tempa et al. (2013) reported a minimum of seven individual Clouded leopards in the park, and Dhendup et al. (2016) reported a minimum of 11 . However, an increasing population of people and a porous land border with India has raised challenges to the integrity of the park and is threatening its wildlife. The goal of this study was to gain insights into the distribution and conservation status of Clouded leopards in the Royal Manas National Park.

\section{Material and Methods \\ Study area}

The Royal Manas National Park (RMNP) is located in the southern part of Bhutan (Fig. 2) and is the oldest protected area in the country. With an area of $1054 \mathrm{~km}^{2}$ and an altitude ranging 
from $100 \mathrm{~m}$ a.s.1. to $\sim 3500 \mathrm{~m}$ a.s.1., the park has diverse forest types from sub-tropical to temperate montane forests and is extremely rich in flora and fauna. It shares boundaries with the Jigme Singye Wangchuck National Park to the north and the Manas National Park in India to the south. Within the country, it is connected with a few other protected areas by biological corridors. The park has 558 plant species, 65 mammal species, 486 bird species, 69 fish species and more than 180 butterfly species recorded till date (RMNP, 2015).

For management purposes, the park area is divided into three zones: the core zone where human-related activities are prohibited except for regulated research, monitoring programs and patrolling. These areas contain prime habitats of endemic, rare and endangered species, with high biological diversity; the multiple use zone which is designated for resource allocation to the local communities residing within the park area; and the buffer area which is outside the park but under the purview of the park management. In 2014, a total population of 8936 people lives in the park of which 5331 live in the multiple use zone, and 3605 in the buffer zone (RMNP, 2015).

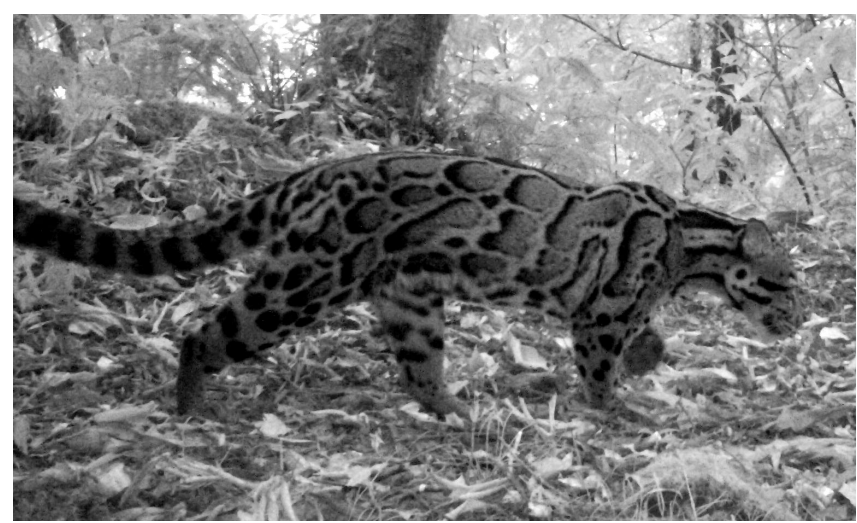

Fig. 1. Clouded leopard (Neofelis nebulosa) camera trapped in Royal Manas National Park.

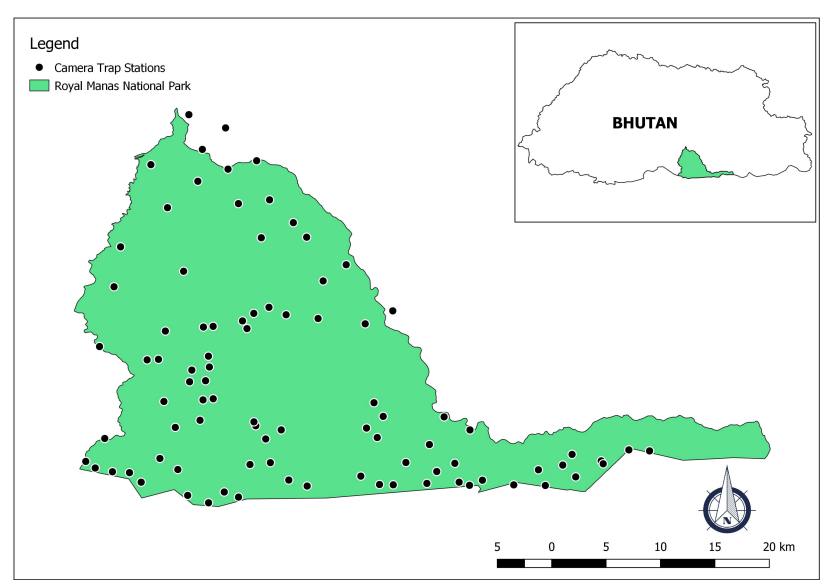

Fig. 2. Map of the Royal Manas National Park with locations of camera trap stations used for long-term monitoring of tigers.

\section{Methods}

Camera trapping data from a tiger survey conducted in 2013-2014 were used to study the distribution of the Clouded leopard. In the interest of optimising survey efforts, the hilly northern part of the park was superimposed with survey grids of $5 \mathrm{~km}$ $\times 5 \mathrm{~km}$, and the southern plains with $2.5 \mathrm{~km} \times 2.5$ $\mathrm{km}$. Locations were searched to maximise the capture probabilities of tigers. At each station, two cameras were set up to capture both flanks of an animal and were kept at about $50 \mathrm{~cm}$ above the ground, and few meters away from each other to avoid flashes from one camera disturbing the other one. Eighty-nine camera stations were initially set across the study area. However, data from only 69 stations were available at the time of analysis: some cameras were lost, elephants damaged some, and a few could not be retrieved due to swollen rivers during the field season. The survey accumulated an effort of 6593 trap days.

After organising the camera trap data into camera trap station folders and species folders, we obtained the GPS coordinates of the Clouded leopard locations. We visited these locations, and identified threats using IUCN - Conservation Measures Partnership Classification of Direct Threats Version: 3.2 (Salafsky et al., 2008). We also reviewed the literature on current activities in the park mainly developmental, resource allocations and illegal activities. Maps were prepared using the QGIS version: 3.2.0 (QGIS Development Team, 2018).

\section{Results and Discussion \\ Distribution}

Clouded leopards were recorded at 17 camera trap stations ( $25 \%$ of the total) within the jurisdiction of the Royal Manas National Park (Fig. $3)$. The species was recorded in cool evergreen broad-leaved forest, deciduous broad-leaved forest, and bamboos and used human trails, river banks, and feeder roads. The species occurred at altitudes ranging from $243 \mathrm{~m}$ a.s.l. to $2323 \mathrm{~m}$ a.s.l. However, they can be found at even higher altitudes. Penjor et al. (2018) obtained records at $3600 \mathrm{~m}$ a.s.l. in Bhutan. Camera traps also photographed prey species which included Assamese macaque (Macaca assamensis (M'Clelland, 1840)), capped langur (Trachypithecus pileatus (Blyth, 1843)), kalij pheasant (Lophura leucomelanos (Latham, 1790)), jungle fowl (Gallus gallus (Linnaeus, 1758)), common palm civet (Paradoxurus hermaphroditus (Pallas, 1777)), masked palm civet (Paguma larvata (C.E.H. Smith, 1827)), large Indian civet (Viverra zibetha (Linnaeus, 1758)), barking deer 
(Muntiacus muntjak (Zimmermann, 1780)), sambhar (Rusa unicolor (Kerr, 1792)), Himalayan serow (Capricornis thar (Hodgson, 1831)), goral (Naemorhedus goral (Hardwicke, 1825)), and wild boar (Sus scrofa (Linnaeus, 1758)).

The camera trap records show a higher Neofelis nebulosa presence in the multiple use zone (ten stations) than the core zone (seven stations) and none in the buffer zone. It is a cause for concern because the multiple use zone permits developmental activities such as the construction of roads, transmission lines, community forestry, industry, and house construction. Within the multiple use zone, one station was reported in a Forest Management Unit and two in Working Schemes. Forest Management Units and Working Schemes are created to meet the demands for timber and other forest resources and are guided by management plans to ensure sustainability and ecological stability.

\section{Conservation Threats}

Neofelis nebulosa is declining in population across its range due to (1) direct exploitation, (2) range fragmentation, and (3) reduction in habitat quality (Grassman et al., 2016). As a species vulnerable to poaching and habitat loss, the Clouded leopard should also be a priority for the park management along with tigers (Panthera tigris (Linnaeus, 1758)) and elephants (Elephas maximus (Linnaeus, 1758)). The species lacks a proper assessment (WWF, 2015; RMNP, 2015) which is mainly due to a lack of funds and studies (Penjor et al., 2015; Dhendup et al., 2016). Threats to Clouded leopards in Royal Manas National Park are broadly pronounced into habitat degradation and loss, poaching, and climate change. The threats are summarised in Table 1.

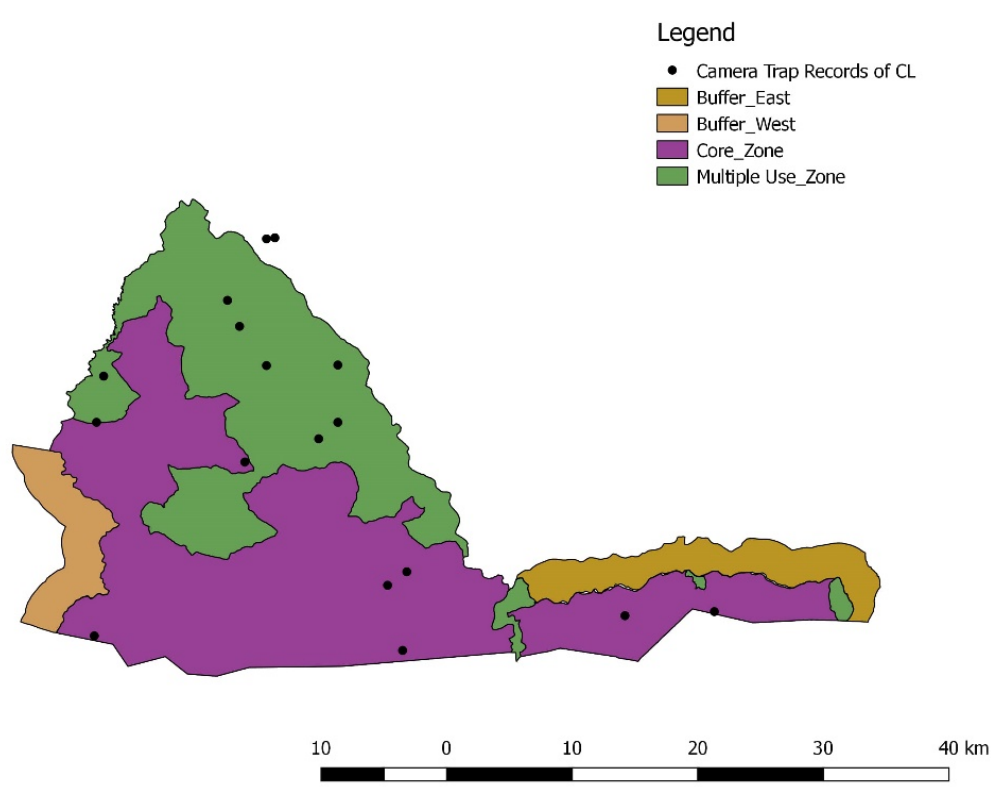

Fig. 3. Distribution of Neofelis nebulosa against different management zones in Royal Manas National Park.

Table 1. Summary of threats to Clouded leopards in Royal Manas National Park (Adapted from IUCN-CMP classification of direct threats. Ver. 3.2)

\begin{tabular}{|c|c|}
\hline Threats & Timing \\
\hline 1. Residential and commercial development $->1.1$. Housing and urban areas & Ongoing \\
\hline 1. Residential and commercial development $->1.3$. Tourism and recreation areas & Ongoing \\
\hline 2. Agriculture and aquaculture $->2.1$. Annual and perennial non-timber crops $->2.1 .2$. Smallholder farming & Ongoing \\
\hline 2. Agriculture and aquaculture $->2.3$. Livestock farming and ranches $->2.3 .1$. Nomadic grazing & Ongoing \\
\hline $\begin{array}{l}\text { 2. Agriculture and aquaculture }->2.3 \text {. Livestock farming and ranches }->\text { 2.3.2. Smallholder grazing, } \\
\text { ranching or farming }\end{array}$ & Ongoing \\
\hline 4. Transportation and service corridors $->4.1$. Roads and railroads & Ongoing \\
\hline 4. Transportation and service corridors $->4$.2. Utility and service lines & Ong \\
\hline $\begin{array}{l}\text { 5. Biological resource use }->5.1 \text {. Hunting and collecting terrestrial mammals }->\text { 5.1.2. Unintentional effects } \\
\text { (species being assessed is not the target) }\end{array}$ & Ongoing \\
\hline $\begin{array}{l}\text { 5. Biological resource use }->\text { 5.2. Gathering terrestrial plants }->5.2 .2 \text {. Unintentional effects (species being as- } \\
\text { sessed is not the target) }\end{array}$ & Ongoing \\
\hline 5. Biological resource use $->$ 5.3. Logging and wood harvesting $->$ 5.3.3. Intentional effects: subsistence/small scale & Ongoing \\
\hline $\begin{array}{l}\text { 5. Biological resource use }->\text { 5.4. Fishing and harvesting aquatic resources }->\text { 5.4.3. Unintentional effects: } \\
\text { subsistence/ small scale }\end{array}$ & Ongoing \\
\hline 6. Human intrusion and disturbance $->6.1$. Recreational activities & Ongoing \\
\hline 6. Human intrusions and disturbance $->6.2$. War, civil unrest, and 1 & oing \\
\hline
\end{tabular}


Habitat degradation and loss. There is a mounting pressure on the park's natural resources to meet the demands for housing, space for construction of roads (Table 2), laying of electric transmission lines and various other habitat conversions. Logging, surface collection of sands and stones, and collection of nonwood forest products (NWFP) occur in multiple use and buffer zones through park-issued permits. The results from a socio-economic survey conducted in 2015 found that all the 640 households interviewed (there are 1183 households in total within the park's jurisdiction) collected non-wood forest products (UWICER, 2015). The collections also occur illegally. The park recorded 20 offenses related to non-wood forest products and 34 offenses related to timber from 2011-2014 (RMNP, 2015). Illegal logging is more common along the IndoBhutan border than within the park. In 2011, the Indian forestry officials in Indian Manas reported seizing 37 truckloads and 231 handcarts of timber coming from Bhutan in one month (The Bhutanese, 2012).

Forest fires and grazing is also a cause for concern. Forest fires are set on deliberately and sometimes unintentionally by cattle herders (Bhutanese and Indians), NWFP collectors, poachers and through uncontrolled grassland management from the Indian side. A land allocation program for the landless people has also partially led to the loss of forest habitat and is exerting more pressure on the protected area. These activities impair Clouded leopards directly or indirectly and put the species under various stresses. The stress can be at an ecosystem level such as habitat conversion and degradation and the species level such as disturbance, and other indirect effects.

Poaching. There are currently no records of Clouded leopard poaching in the park. However, it is recognisably an immediate threat, particularly along the Indo-Bhutan border. Generally, poaching in the park is reported in three forms: commercial, subsistence and retaliation killing (WWF, 2015). While commercial and subsistence poaching occurs throughout the park including the core zone, retaliatory killings happen mostly near the settlements (Fig. 4), due to livestock and crop depredations. The park management seized one set of tiger bones and two numbers of Asiatic elephant tusks from Indian poachers in recent years and also reported 21 offenses related to fishing from 2011-2014 (RMNP, 2015). It is very likely that Clouded leopards are a bycatch for poachers while they hunt tigers and other wildlife of economic importance. The species also suffer from snares which are often set up by villagers near agricultural fields to protect crops from wild pest (ICS, 2016). Prey depletion is another cause for concern.
Table 2. Details of roads in the Royal Manas National Park (Source: RMNP, 2015)

\begin{tabular}{|c|c|}
\hline Road category & Length, $\mathrm{km}$ \\
\hline National highway & 110 \\
\hline Farm/feeder roads & 66.48 \\
\hline Forest/seasonal roads & 36.3 \\
\hline Access/ temporary road & 3.43 \\
\hline
\end{tabular}

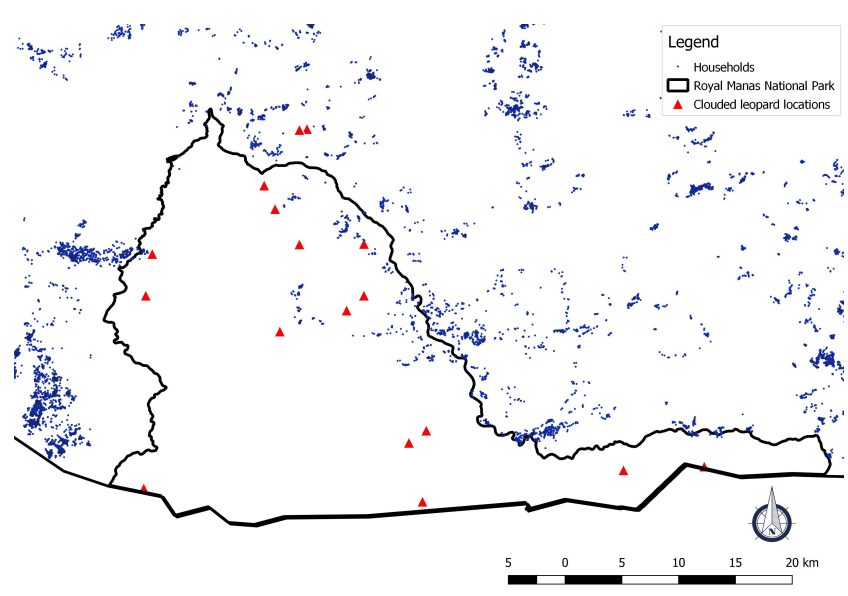

Fig. 4. Neofelis nebulosa locations against settlements in Royal Manas National Park.

Climate change vulnerability. RMNP assessed climate change vulnerability for various species and ecosystems within the park. Clouded leopard showed a moderate vulnerability to climate change impact as the species is a generalist regarding diet and habitat use and it has a good food source in the park.

\section{Conclusions}

Clouded leopard suffers from habitat loss, disturbance and unintentional snaring or directed poaching. The species is known to be less adaptable to disturbance and avoids habitats around human settlements (Wilting et al., 2006; Tan et al., 2017). While the forest type (whether primary or selectively logged) does not seem to affect the Clouded leopard habitat use (Mohamad et al., 2015), human activity can affect it in a negative manner (Clements, 2013). Like elsewhere, even in Bhutan, felid responses to impacts of degradation to existing habitats are poorly understood (Tantipisaunh et al., 2014). It is crucial to regulate infrastructural development and allocation of natural resources particularly timber in the multiple use zones. Strategies that make anti-poaching effective will also need to be implemented, and other appropriate practices for species conservation need to be set up. There is also an evident lack of reliable information on the Clouded leopard population, current habitat conditions, and threats. Therefore, the status of 
the Clouded leopard needs to be assessed in detail through dedicated studies to facilitate proper planning and conservation interventions.

\section{Acknowledgments}

I would like to thank the Ugyen Wangchuck Institute for Conservation and Environmental Research and Royal Manas National Park, Dr. Tshering Tempa, Sangay Wangchuk, Tshering Dendup, Ugyen Penjor, Jim Sanderson, Kezang Wangchuk, Leki and the two anonymous reviewers. Funding was provided by the Rufford Foundation and the National Geographic Society. IdeaWild is being thanked for providing equipment assistance.

\section{References}

Austin S.C., Grassman L.I., Tewes Jr M.E., Silvy N.J. 2007. Ecology and conservation of the leopard cat Priornailurus bengalensis and clouded leopard Neofelis nebulosa in Khao Yai National Park, Thailand. Acta Zoologica Sinica 53: 1-14.

Clements G.R. 2013. The Environmental and Social Impacts of Roads in Southeast Asia. ResearchOnline@JCU, James Cook University. Available from https://researchonline.jcu.edu.au

Dhendup T., Tempa T., Tenzin U. 2016. Clouded Leopard co-exists with six other felids in Royal Manas National Park. Cat News 63: 23-26.

DoFPS. 1995. Forest and Nature Conservation Act of Bhutan. Thimphu: Bhutan. Department of Forest and Park Services. 23 p.

Gordon C.H., Stewart E.A.M. 2007. The use of logging roads by a solitary felid, the clouded leopard. Cat News 47: 12-13.

Grassman L., Lynam A., Mohamad S., Duckworth J.W., Bora J., Wilcox D., Ghimirey Y., Reza A., Rahman H. 2016. Neofelis nebulosa. In: The IUCN Red List of Threatened Species 2016: e.T14519A97215090. Available from: http://dx.doi.org/10.2305/IUCN.UK.2016-1. RLTS.T14519A97215090.en

ICS. 2016. Rare and elusive Clouded Leopard rescued from Punakha. Ministry of Agriculture and Forest, Royal Government of Bhutan. Available from http:// www.moaf.gov.bt/rare-and-elusive-clouded-leopardrescued-from-punakha/

Mohamad S.W., Rayan D.M., Christopher W.C.T., Hamirul M., Mohamed A., Lau C.F., Siwan E.S. 2015. The first description of population density and habitat use of the mainland clouded leopard Neofelis nebulosa within a logged-primary forest in South East Asia. Population Ecology 57: 495-503. DOI: 10.1007/s10144-015-0494-1

Penjor U. 2015. The conservation of clouded leopard Neofelis nebulosa (Griffith, 1821) in Bhutan. Journal of the Bhutan Ecological Society 2: 59-65.

Penjor U., Macdonald D.W., Wangchuk S., Tandin., Tan C.K.W. 2018. Identifying important conservation areas for the clouded leopard Neofelis nebulosa in a mountainous landscape: Inference from spatial modeling techniques. Ecology and Evolution 8(8): 4278-4291. DOI: $10.1002 /$ ece 3.3970

QGIS Development Team. 2018. QGIS Geographic Information System. Open Source Geospatial Foundation Project. Available from http://qgis.osgeo.org

RMNP. 2015. Conservation Management Plan: Royal Manas National Park 2015-2019. Gelephu: Bhutan. Department of Forest and Park Services. $134 \mathrm{p}$.

Salafsky N., Salzer D., Stattersfield A.J., Hilton-Taylor C., Neugarten R., Butchart S.H.M., Collen B., Cox N., Master L.L., O’Connor S., Wilkie D. 2008. A standard lexicon for biodiversity conservation: Unified classification for threats and actions. Conservation Biology 22(4): 897-911. DOI: 10.1111/j.1523-1739.2008.00937.x

Tan C.K.W., Rocha D.G., Clements G.R., Brenes-Mora E., Hedges L., Kawanishi K., Mohamad S.W., Rayan D.M., Bolongon G., Moore J., Wadey J., Campos-Arceiz A., Macdonald D.W. 2017. Habitat use and predicted range for the mainland clouded leopard Neofelis nebulosa in Peninsular Malaysia. Biological Conservation 206: 65-74. DOI: 10.1016/j.biocon.2016.12.012

Tantipisaunh N., Chutipong W., Ngoprasert D., Lynam A., Steinmetz R., Sukmasuang R., Jenks K.E., Grassman Jr L.I., Cutter P., Kitamura S., Baker M.C., McShea W., Bhumpakphan N., Gale G.A., Reed D.H. 2014. Recent distribution records, threats and conservation priorities of small cats in Thailand. Cat News Special Issue 8: 31-35.

Tempa T., Hebblewhite M., Mills L.S., Wangchuk T.R., Norbu N., Wangchuk T., Nidup T., Dhendup P., Wangchuk D., Wangdi Y., Dorji T. 2013. Royal Manas National Park: A hotspot for wild felids, Bhutan. Oryx 47(2): 207-210. DOI: 10.1017/S0030605312001317

The Bhutanese. 2012. Gun-trotting Indian timber mafia loots Bhutan forests. The Bhutanese newspaper. Available from https://thebhutanese.bt/gun-trotting-indian-timber-mafia-loots-bhutan-forests/

UWICER. 2015. Baseline Report: A Socio-economic survey in Royal Manas National Park. Bumthang, Bhutan: Ugyen Wangchuck Institute for Conservation and Environmental Research. 25 p.

Wilting A., Fischer F., Bakar S.A., Linsenmair K.E. 2006. Clouded leopards, the secretive top-carnivore of Southeast Asian rainforests: their distribution, status and conservation need in Sabah, Malaysia. BMC Ecology 6: 16. DOI: 10.1186/1472-6785-6-16

Wilting A., Buckley-Beason V.A., Feldhrar H., Gadau J., O'Brien S.J., Linsenmair K.E. 2007. Clouded leopard phylogeny revisited: support for species recognition and population division between Borneo and Sumatra. Frontiers in Zoology 4: 15. DOI: 10.1186/1742-9994-4-15

WWF. 2015. Enforcement Assessment Royal Manas National Park. Thimphu, Bhutan: Worldwide Fund for Nature Bhutan \& Tiger Alive Initiative. 24 p. 
РАСПРОСТРАНЕНИЕ И ОХРАННЫЙ СТАТУС NEOFELIS NEBULOSA (FELIDAE) В КОРОЛЕВСКОМ НАЦИОНАЛЬНОМ ПАРКЕ МАНАС (БУТАН)

\author{
Т. Дендап ${ }^{1,2}$ \\ ${ }^{1}$ Институт природоохранных и естественнонаучных исследований имени Угъена Вангчука, Бутан \\ ${ }^{2}$ Программа биологии дикой природь,, Университет Монтаны, США \\ e-mail:tashid@uwice.gov.bt
}

Дымчатый леопард (Neofelis nebulosa) является угрожаемым видом в глобальном масштабе. Существует недостаток данных о его экологии, распространении, тренде состояния популяции и угрозах. В $2013-$ 2014 гг. мы использовали данные фотоловушек, используемых для долговременного мониторинга тигров Королевского национального парка Манас (Южный Бутан) для изучения распространения дымчатого леопарда и определения угроз для этого вида и мест его обитания. Дымчатый леопард был зарегистрирован на 17 станциях с фотоловушками (25\% от общего числа станций), расположенных на территории, подведомственной национальному парку. Из них десять станций были расположены в пределах зоны экстенсивного использования и управления национального парка и семь - в зоне «ядра» ООПТ. Высоты наблюдений варьировали от 243 м н.у.м. до 2323 м н.у.м. Вид постоянно сталкивается с угрозами нарушения и уничтожения среды обитания, браконьерства и изменения климата. Добыча ресурсов и мероприятия по развитию территории национального парка в местах обитания дымчатого леопарда в зоне экстенсивной эксплуатации должны изучаться и строго контролироваться. В дальнейшем усилия по проведению активного мониторинга должны быть продолжены, в частности на границе Индии и Бутана. Существует также острая необходимость в проведении специальных экологических исследований и детальной оценке факторов, угрожающих этому виду.

Ключевые слова: биоразнообразие, браконьерство, Бутан, дымчатый леопард, потеря среды обитания, сохранение, фотоловушка 